\title{
POLYCULTURALITY AS A FACTOR OF EVENT TOURISM DEVELOPMENT IN UKRAINE
}

\author{
'Tamara BULYCHEVA, Kateryna BUTKALIUK, Tetiana GRYNIUK
}

National Pedagogical Dragomanov University, Kyiv, Ukraine

'lilacsky53@gmail.com

\begin{abstract}
The article substantiates the popularity of event tourism in the world in general and individual countries in particular. The need to study the demand for event tourism and the impact of multiculturalism as an important factor in its development is emphasized. It was found that its rapid development is due to a combination of ethnonational and ethnocultural features of specific areas, the participation of travellers in contemplating the cultural identity of a particular area, the richness of the program, entertainment, brightness, festive atmosphere. It is shown that in Ukraine and its regions there are real opportunities for active development of event tourism on the basis of ethnonational and ethnocultural features of its territory, as it is multinational and, consequently, multicultural. It is determined that the problems of studying the influence of ethnonational and ethnocultural features of individual territories on the development of tourism within them and social and economic development in general are complex. The relationship between multiculturalism and the development of event tourism is proved taking into account the ethnonational features of the regions of Ukraine. An example is given that demonstrates the current situation of event tourism development in the Odessa region on the basis of multiculturalism.
\end{abstract}

Key words: tourism, types of tourism, event, event tourism, culture, multiculturalism, ethnonational, ethnocultural.

DOI: https://doi.org/10.17721/2413-7154/2020.84.35-41

UDC: 379.85

Received: October 21, 2020.

Revised: December 5, 2020.

Accepted: December 23, 2020.

\section{ПОЛІКУЛЬТУРНІСТЬ ЯК ЧИННИК РОЗВИТКУ ПОДІЄВОГО ТУРИЗМУ В УКРАЇНІ}

'Тамара БУЛИЧЕВА, Катерина БУТКАЛЮК, Тетяна ГРИНЮК

Національний педагогічний університет імені М. П. Драгоманова, Київ, україна

1lilacsky53@gmail.com

\begin{abstract}
Анотація: В статті обґрунтовується популярність подієвого туризму в світі загалом і окремих країнах. Розкривається необхідність вивчення туристичного попиту на подієвий туризм та впливу полікультурності як важливого чинника його розвитку. Виявлено, що його стрімкий розвиток відбувається завдяки поєднанню етнонаціональних та етнокультурних особливостей конкретних територій, участі мандрівників у спогляданні культурної ідентичності певної місцевості, також насиченості програми, видовищності, яскравості, атмосфери свята. Показано, що в Україні та її регіонах $\epsilon$ реальні можливості для активного розвитку подієвого туризму на базі етнонаціональних та етнокультурних особливостей її території, оскільки вона $\epsilon$ багатонаціональною, а, отже, полікультурною. Визначено, що проблематика дослідження впливуетнонаціональних та етнокультурних особливостей окремих територій на розвиток туристичної діяльності в їх межах та соціально-економічний розвиток загалом комплексна. Доведено взаємозв'язок між полікультурністю і розвитком подієвого туризму з огляду на етнонаціональні особливості регіонів України. Наведений приклад, що демонструє сучасну ситуацію розвитку подієвого туризму в Одеському регіоні на основі полікультурності.

Ключові слова: туризм, види туризму, подія, подієвий туризм, культура, полікультурність,
\end{abstract} етнонаціональний, етнокультурний. 
Постановка проблеми. Нині популярність подієвого туризму невпинно зростає. Незважаючи на молодий вік, він перебуває на підйомі свого розвитку. Bсе більше туристів має бажання долучитись до найрізноманітніших подій - природних, національноісторичних, політичних, спортивних, культурнорозважальних тощо, стати частиною світових дійств. За оцінкою Всесвітньої туристичної організації (UNWTO) подієвий туризм наданий час $є$ одним 3 найперспективніших видів туризму у світі. Серед інших видів туризму він вражає своєю насиченістю програми, видовищністю, яскравістю та атмосферою свята. Ще однією особливістю такого виду туризму є невичерпність його ресурсів (Frolova, 2010).

Потужним туристсько-рекреаційним ресурсом цього виду туризму стали етнонаціональні та етнокультурні особливості окремих континентів, регіонів, країн, адміністративних та етнографічних областей, населених пунктів. В силу цього ресурсна база подієвого туризму необмежена та досить різноманітна, особливо за умов його оптимальної організації.

Україна та їі регіони володіють унікальним полікультурним потенціалом, який може бути активно включений до соціально-економічних процесів загалом i розвитку подієвого туризму зокрема. Нині відбувається активна інтеграція України до світового культурного простору. Тому повноцінне та всебічне виявлення й вивчення культурної спадщини 3 метою раціонального використання i збереження ㄲï - стратегічне завдання держави. Вивчення, аналіз і оцінювання культурної спадщини $\epsilon$ необхідною умовою планування розвитку регіону, адміністративного району, міста та села, оскільки має економічну користь і $€$ важливим чинником їх розвитку.

В Україні та їі регіонах є реальні можливості для активного розвитку подієвого туризму на базі етнонаціональних та етнокультурних особливостей iii території, оскільки вона є багатонаціональною, а, отже, полікультурною. Але необхідно, як це зазначено в Законі України «Про туризм», забезпечити раціональне використання та збереження туристичних ресурсів. Адже, подія, як туристичний ресурс, має яскраво виражений мультиплікаційний ефект вона «змушує» розвиватися різні сектори туристичної індустрії для ефективнішого використання власного потенціалу. Це зумовлює необхідність вивчення туристичного попиту на подієвий туризм та впливу полікультурності як важливого чинника його розвитку.

Аналіз останніх публікацій. Наукове обгрунтування нових видів туризму є предметом широких міждисциплінарних досліджень, a їх історія та чинники розвитку, характерні особливості, ресурсна база вивчається різними науковими школами та напрямами. Проблематика дослідження впливу етнонаціональних та етнокультурних особливостей окремих територій на розвиток туристичної діяльності в їх межах та соціально- економічний розвиток загалом комплексна. Про це свідчить участь у їі розробці представників різних наукових дисциплін - культурологів, істориків, мистецтвознавців, етнографів, археологів, архітекторів, географів, економістів, фахівців туристичної галузі тощо.

Серед науковців, що зробили вагомий внесок у вивчення подієвого туризму, слід відмітити праці економістів Ю. Блохіної, О. Богданової, M. Кабушкіна, П. Тищенко (Tishchenko, 2011), О. Шикіної (Shikina \& Liptuga, 2017; Shikina \& Oliynyk, 2016). Однак, це дослідження переважно економічного профілю. Серед туризмознавців виділяються роботи О. Бабкіна (Babkin, 2008), M. Біржакова (Birzhakov, 2000), Д. Ісмаєва, В. Квартальнова, I. Давиденка (Davydenko, 2012). Як історико-культурне явище подієвий туризм охарактеризований Л. Устименко (Smal, 2010; Tereshkovich, 1998). Серед економіко-географів, що займаються вивченням окремих видів туризму i, зокрема, подієвого, слід відзначити О. Любіцеву, М. Мальську, І. Смирнова, Т. Ткаченко, В. Федорченка, О. Бейдика, Н. Новосад, І. Смаля, О. Топалову та ін. (Beidyk, 2001; Beidyk et al., 2016; Oliynyk \& Shikina, 2016).

У своїх працях науковці акцентують увагу на визначенні основних термінів, особливостей та дефініцій подієвого туризму, висвітлення ролі подієвого туризму в економічному розвитку країни, як на національному, так і на локальному рівнях, дослідженні івент-менеджменту, як складової подієвого туризму, аналізі типології запланованих подій. Зроблений аналіз сучасного стану подієвого туризму в світі та перспектив його розвитку в Україні, висвітлені питання створення та просування подієвих турів на теренах нашої держави, підвищення якості послуг, пов'язаних 3 проведенням подій, виділені лімітуючи чинники розвитку. Завдяки сучасним дослідженням подієвий туризм виділився в самостійну галузь науки зі своїм термінологічним апаратом і став розглядатися як окремий напрям.

Що ж до етнонаціональних та етнокультурних особливостей конкретної території, культурних ресурсів загалом, культурної трансформації, полікультурності, то аналіз наукової літератури засвідчує, що в останні роки ці питання висвітлюються у працях зарубіжних та вітчизняних науковців. Головно, це праці культурологів, зокрема, В. Шейка (Sheiko, 2012, 2017), О. Бойко (Boyko, 2011a, 2011b). Проблематика культурних трансформацій у туризмі представлена у працях Л. Божко (Bozhko, 2017). Публікацій, присвячених вивченню полікультурності як чинника розвитку подієвого туризму з суспільногеографічних позицій не так вже й багато, особливо коли йдеться про регіональний аспект дослідження.

Постановка завдання. Метою даної публікації $\epsilon$ показати, що стрімкий розвиток подієвого туризму відбувається завдяки його поєднанню 3 етнонаціональними та етнокультурними особливостями народів конкретних територій 
(окремих континентів, регіонів, країн, адміністративних та етнографічних областей, населених пунктів), насамперед спогляданню культурної ідентичності на певній території; вивчення подієвого туризму в контексті полікультурних особливостей окремих регіонів України і виявлення взаємозв'язку між полікультурністю i розвитком подієвого туризму 3 огляду на етнонаціональні особливості території; навести приклади, які демонструють сучасну ситуацію розвитку подієвого туризму в регіоні.

Виклад основного матеріалу. Земля як планета існує у Всесвіті вже більше 5 мільярдів років. Сфера живого на планеті існує приблизно 3,5 мільярдів років. Людина в природі з'явилась 3-3,5 млн. років тому. А явище «культури» відоме людству лише з IV століття до нашої ери.

Проблемам культури приділялась увага ще в епоху античності. Так, Демокрітом і Тітом Лукрецієм Каром були сформульовані перші концепції антропосоціогенезу. Ідея про природно-географічну зумовленість соціально-психологічних і політичних явищ була запропонована Гіппократом. Корнелій Таціт, як, ймовірно, перший етнограф, протиставив цивілізаційний розвиток дикунству (Pazenok \& Fedorchenko, 2004).

$\mathrm{Te}$, в якому сенсі ми і наші попередники декілька поколінь тому розуміли поняття «культура», те, який сенс та властивості вкладали, сформувалося лише у XVI-XVIII - на початку XIX ст. в Західній Європі. 3 іменами Пьєтро Мартіна, Мішеля де Монтеня, Жана Жака Руссо і Дені Дідро пов'язана концепція «щасливого дикуна», яка ідеалізувала суспільний лад «примітивних» народів (мала широку популярність) (Frolova, 2010).

До першої половини XIX ст. феномен культури розглядався через раціональне осмислення морально-правових, естетичних норм життя, філософсько-теоретичної свідомості. У другій половині XIX ст. 3 розвитком різних наук про людину, культура стала досліджуватись в межах низки науково-концептуальних напрямів цих наук. Так, з'явився лінійний еволюціонізм, який розглядав культуру людства як перехід від простих форм до більш складних. Основним об'єктом дослідження еволюціоністів (Джеймс Фрезер, Люсьєн Леві-Брюль) було корінне населення колоній в Африці, Південній Америці, Південно-Східній Азії.

На початку XX ст. у дослідженні культури з'являється функціональний підхід, який дозволив розглядати ii як цілісне утворення, що складається 3 окремих елементів, частин. Кожна «атомарна клітинка» культури досліджується не як випадкове (архаїчне) утворення (пережиток), а яка виконує певну функцію в соціокультурній спільноті. Основою такого підходу є теорія потреб (Belik, 1999).

У другій половині XX ст. дифузіоністська концепція культури (Babkin, 2008) доводить, що глобалізація зумовлює уніфікацію культур i що в основі цього процесу $є$ запозичення культур. Вивчалися колоніальні контактні ситуації, які демонстрували вплив розвиненішої активної культури на менш розвинену, пасивну.

На початку XXI ст. завдяки трансформаційним процесам створюються нові ціннісні орієнтації. Туризм, зокрема подієвий, стрімко розвивається, оскільки існує розмаїття й унікальність культурного та природного середовища. Нині замість знищення національних культур і природних територій здійснюється їх збереження та розвиток. Місцеве населення, щоб привернути увагу зарубіжних та вітчизняних туристів, готуючи якесь дійство (подію), використовує елементи побуту, дотримується стародавніх традицій, виконує різні обряди, відзначає свята, одягається в національні костюми. Такий національний колорит зацікавлює представників інших культур. Розвиток туризму називають умовою цих процесів (Shikina \& Liptuga, 2017).

Світова культура неосяжна, вона барвиста i нагадує вітраж готичного храму, кожне скельце якого несе свою ідею, додає свого забарвлення, складає свій малюнок. Вона розкладається на більш вужчі культури: континентів, регіонів, країн, адміністративних та етнографічних областей, населених пунктів. Культура навіть одного населеного пункту не однобока, не представлена чимось одноманітним - це світ в мініатюрі. Вражає глобальність, насиченість, диференційованість і в той же час сакральне поєднання всіх елементів. Безглуздо вживати термін монофонії для опису культури будь-якої з епох, адже навіть у найперших проявах цього архаїчно-модерного явища прослідковується різкий контраст елементів.

Населення України являє собою широкий спектр різних національностей. Кожна етнічна група має свою виражену ідентичність, а взаємодія культур та релігій $є$ важливою справою для такої багатонаціональної держави як Україна. Надзвичайно актуальним є формування полікультурного менталітету, сприйняття культурного плюралізму, загальнолюдських цінностей, толерантного ставлення до інших культур та традицій. У зв'язку 3 цим особливого значення набуває подієвий туризм як одна 3 найбільш перспективних та динамічних галузей відпочинку в світі.

Подієвий туризм - це неминуща атмосфера свята, індивідуальні умови відпочинку і незабутні враження. Головна особливість подієвого туризму - безліч яскравих неповторних моментів (Babkin, 2008). 3 іншого боку, подієвий туризм - складова культурного туризму, пов'язана 3 певною подією в суспільному житті; подорож, пов'язана 3 цікавою для туриста подією (Beydik, 2001; Interesting Places of Ukraine, 2020a, 2020b); поїздки з метою задоволення потреби у відвідуванні будь-якого заходу (Tishchenko, 2011); вид туристської діяльності, що приваблює туристів різноформатними громадськими заходами культурного або спортивного життя, які сприяють розвитку інфраструктури туризму, інтеграції різних верств населення в суспільство i формуванню позитивного іміджу дестинації (Alekseeva, 2012); туристська діяльність, пов'язана 3 різноманітними значущими суспільними подіями, a також рідкісними природними явищами, шо 
привертають своєю унікальністю, екзотичністю, неповторністю велику кількість туристів 3 різних країн (Alekseeva, 2012; Interesting Places of Ukraine, 2020a, 2020b; Tishchenko, 2011).

Характерною особливістю сучасного етапу розвитку туризму $є$ зростання інтелектуальних вимог туристів, яким притаманне бажання комплексного ознайомлення 3 територією, бажання знати чим та як вона живе, відчути дух, стиль та темп ㄲï життя. Особливостями подієвого туризму є: відсутність сезонності; можливість прогнозування; масовість; інтерактивність; інноваційність; регулярність подій; стимулювання повторного відвідування дестинацій; видовищність (Beidyk et al., 2016).

Одночасно подієвий туризм $є$ важливим пріоритетом розвитку національного туристичного ринку країни, стабілізуючим чинником ринку робочої сили. Він може позитивно впливати на обсяг капіталовкладень у національні підприємства сфери туризму, на вирівнювання рівнів життя в регіонах країни, на зняття соціальної напруги в полікультурному середовищі.

Подієвий туризм, допомагаючи усунути бар'єри між представниками різних культур та національностей, створює атмосферу миру та розуміння. Суспільно-культурне багатство окремих регіонів України - архітектура, одяг, спосіб господарювання, прив'язаність до землі, духовна сфера, звичаї та традиції створюють особливу неповторність. Зберігаючи таку полікультурну спадщину, варто робити все можливе, щоб контакти між народами та етнічними групами безперервно розвивались та підтримувались. Такий обмін дає прекрасний шанс взаємопізнання, виховує почуття гордості за власну самобутність та одночасно формує толерантність до «відмінностей» сусідів. Розвиток подієвого туризму є одним 3 найефективніших та найдієвіших механізмів створення та поширення позитивного іміджу регіону, де пропонується певний набір послуг, що відповідає попиту туриста на перевезення, проживання, харчування, відпочинок, розваги тощо.

Україна є давнім потужним центром слов'янської культури 3 величезним культурноісторичним потенціалом. Починаючи з Трипільської та Черняхівської культур, Давньої Русі в Україні формувались та нашаровувались різні культурні надбання, які створюють необмежену можливість для полікультурного подієвого туризму в наш час. Подісвий туризм може розглядатись як важливий фактор довгострокових програм та стратегій збалансованого регіонального розвитку з метою підвищення рівня національно-патріотичного виховання молоді, відродження духовності, формування гармонійно-розвиненої особистості та розширення світогляду.

Серед напрямів подієвого туризму в Україні за останні 20-25 років найбільш репрезентативними були мистецькі (музикальні, літературні, танцювальні, співочі) та гастрономічні фестивалі, ярмарки, релігійні паломництва.
Серед найвідоміших фольклорно-етнографічних фестивалів слід відзначити такі: Дзвони Лемківщини (урочище Бичова біля м. Монастириська, Тернопільська область), Жнива (Київ), Етновир (Львів), Міжнародний гуцульський фестиваль (міста Гуцульщини), Свіччине весілля (с. Березова Рудка, Полтавська область), Гребінчині вечорниці (м. Гребінка, Полтавська область), Купальські роси (с. Немиренці, Житомирська область), Київська Русь (с. Копачі, Київська область), Етнофестиваль «Шешори» (с. Шешори, Івано-Франківська область), Гуморина (м. Одеса).

Фестивалі давньої та середньовічної культури знайшли своє відображення в таких дійствах: Трипільське коло (м. Ржищів, Київська область), Живий вогонь (м. Вінниця, м. Хмільник), Срібний Тотош (с. Чинадієво, Закарпатська область), Терра Героїка (м. Кам'янець- Подільський, Хмельницька область), Львів стародавній (Львів), Ту Стань! (с. Урич Сколівського району, Львівська область), Під покровом тризуба (м. Боярка, Київська область), Битва націй (м. Чернівці).

Гастрономічнй туризм повною мірою відповідає соціально-гуманітарній місії туристичної діяльності як чинника діалогу культур, поваги до загальнолюдських цінностей, толерантності до способу життя, світогляду та традицій, оскільки національна кухня є невід'ємною частиною культурної спадщини кожної нації, оригінальним надбанням будь-якого етносу. Найяскравішими щорічними подіями у гастрономічній сфері були: КоропФест (с. Коропець, Тернопільська область), Галицька Дефіляда (м. Тернопіль), Борщик у глиняному горщику (м. Опішня, Полтавська область), Міжнародний фестиваль дерунів (м. Коростень, Житомирська область ), Закарпатське божолє (м. Ужгород) (Antonenko, 2005; Oliynyk \& Shikina, 2016).

Лімітуючими чинниками, що негативно впливають на розвиток подієвого туризму, є слабо розвинена туристська інфраструктура, низька інвестиційна та ділова активність місцевого населення, нестача кваліфікованих кадрів, слабке інформаційне просування заходу, незначне використання туристського потенціалу (Beydik, 2001).

Серед регіонів України значним історикокультурним потенціалом володіє Одеська область. Серед наукових розробок, присвячених вивченню та систематизації культурної спадщини, краєзнавчих матеріалів, пам'яток історії та культури області прослідковується тенденція до виокремлення явища полікультурності, як одного з головних чинників розвитку туризму. В останніх дослідженнях таких авторів, як О. Присяжнюк, М. Петрова, В. Кушнір, С. Булатович та ін. увага зосереджена на проблемах вивчення проявів культури народів, що проживали на території Одеської області.

Дослідження особливостей впливу різних культур та народностей на формування культурного середовища Одеської області та ролі полікультурності для розвитку туризму в регіоні довели, що культура є одним з головних чинників туристсько- 
рекреаційної діяльності. Це підтверджують результати досліджень по інших регіонах України і в світі загалом. Більшість туристичних мандрівок у світі здійснюється саме в пошуках і пізнанні культур окремих континентів, держав, міст, тощо. Культурні мотиви туризму спонукають людей відвідувати об'єкти, які становлять культурну спадщину країн i регіонів: історичні місця, археологічні пам'ятки, музеї, картинні галереї, театри, народне мистецтво тощо.

Заселення територій на березі Чорного моря веде свій початок з пізнього палеоліту (40-13 тис. років тому). У VII-II ст. до н. е. причорноморські степи населяли іраномовні племена скіфів. У VI ст. до н. е. греки-переселенці заснували багато поселень, найвідоміші з яких Тіра і Ніконій, що перебували на протилежних берегах Дністровського лиману. У I-III ст. Північно-Західне Причорномор'я завоювали римляни, на зміну яким прийшли готи (III ст.), а згодом - гуни (IV ст.).

У VIII ст. на межиріччі Дунаю і Дністра осіли алано-болгарські племена, яких за часів Київської Русі витиснули та частково асимілювали слов'яни. В середині XIII ст. край прибрали до рук татаромонголи. В XV ст. задністровська частина потрапила під владу Молдавського князівства, що з середини XV ст. поволі переходить під контроль Туреччини. У 1475 році і Кримське ханство стало васалом османів, а Північне Причорномор'я з того часу майже на три сторіччя перетворюється на один із плацдармів для турецько-татарських нападів на європейські землі.

Після трьох воєн з турками (1768-1774, 1787-1791 i 1806-1812 рр.) Російська імперія повністю відтіснила османів за межі сучасної Одеської області. На причорноморських землях російський уряд заснував місто-порт Одесу, що незабаром перетворилася на головну морську браму півдня імперії. У 1918 році південно-західна частина краю (межиріччя ДністерДунай-Прут) була окупована Румунією, у складі якої та й залишалася до 1940 року (Sheiko, 2012).

Екскурс в історію краю дозволяє констатувати, що кількість народів, що в той чи інший час перебували на цих теренах, близька до 16. Кожен 3 них залишив окремий культурний відбиток у вигляді архітектурних споруд, прикладів містобудування тощо. Можна взяти до уваги давнє, збудоване греками-колоністами, місто Тіра (сучасна назва Білгород-Дністровський). Його культурна цінність приваблює щороку тисячі туристів. Найбільшою пам'яткою стародавнього світу вважається знаменита фортеця - оборонна споруда XIII-XV ст. Вона заснована на високому скелястому березі Дністровського лиману i будувалася протягом майже двох сторіч. Основу кріпосної нездоланності формує грізна цитадель, що нависає над урвищем, яку ще називають Генуезьким замком. Високі і міцні (завтовшки до 5 м) мури 3 вузькими бійницями, величезні вежі 3 шатровими черепичними дахами навіть крізь віки вражають своєю неприступністю (Sheiko, 2017)

Ще одним проявом древнього культу слід вважати Скіфську гробницю, знайдену на околицях міста. Склеп, виявлений у 1895 році, представляє собою двокамерну споруду на скелі. В середині $\epsilon$ орнамент у вигляді візерунка деревини. $€$ припущення, що до Скіфської могили прокладений підземний хід 3 Акерманської фортеці (Nikitina \& Zinchenko, 2012).

До більш пізньої епохи належать Олександрівські казарми, датовані початком 1828-1838 років. Побудовані за указом російського імператора Олександра I з метою зміцнення кордону імперії в Бессарабії. Комплекс займає територію площею 2,6 га на високому березі Дністровського лиману. Складається 3 офіцерських корпусів і солдатських казарм у східному стилі. Решта пам'яток міста представлені храмовими спорудами різних епох та культур: Вознесенський собор, підземна церква Івана Сочавського, Грецька церква, Вірменська церква; міськими спорудами, які з часом втратили початкове призначення: особняк поміщика Ярошевича, Земська управа (приміщення Аграрного технікуму), Чоловіча гімназія (приміщення педагогічного коледжу). Місто залишається цікавим для туристів і для людей мистецтва. Тут було знято і знімається багато кінофільмів 3 історичним підтекстом, серед найбільш відомих - «Мушкетери двадцять років потому» (Doroga.ua, 2020).

Таким чином, розмаїття націй та національностей, що проживали і проживають в Одеському регіоні i зокрема в м. Білгороді-Дністровському, позитивно впливають на сучасний розвиток туризму. Вони створюють непідробний колорит i бажання приїздити знову i знову. Білгород-Дністровський не єдине місто, яке створює настрій туристів в Одеському регіоні, але його самобутність і мікс культур вражає.

Висновки. В наш час українські фестивалі, ярмарки, спортивні та інші заходи, що піднімають туристичний імідж країни, регіону або конкретної місцевості поки що не можуть вийти на гідний міжнародний рівень. Досить перспективним є проведення в Україні етнофестивалів або інших заходів, що представляють полікультурне середо-вище держави. Умовами успішного проведення таких заходів є відповідна державна політика, а також підтримка відомих торгових марок.

\section{References:}

Alekseeva, O. (2012). Event Tourism as a Factor of Socio-Economic Development of the Region. Abstract of PhD Thesis. Moscow. [In Russian]. [Алексеева О. В. Событийный туризм как фактор социально-экономического развития региона : автореф. дисс. на соиск. уч. степени канд. экон. наук. М., 2012. 28 с.]

Antonenko, V. (2005). International tourism as a factor of interaction and mutual enrichment of cultures. In V. Pazenok (Ed.), Philosophical Essays on Tourism (pp. 223-233). Kуiv. [In Ukrainian]. [Антоненко В. Г. Міжнародний 
туризм як чинник взаємодії та взаємозбагачення культур. Філософські нариси туризму: за ред. В. С. Пазенка. K., 2005. C. 223-233.]

Artanovsky, S. (1967). Historical unity of mankind and mutual influence of cultures: Philosophical and methodological analysis of modern foreign concepts. Leningrad, 1967. [In Russian]. [Артановский С. Н. Историческое единство человечества и взаимное влияние культур: Философско-методологический анализ современных зарубежных концепций. Ленинград, 1967]

Babkin, O. (2008). Special Types of Tourism. Rostov-on-Don. [In Russian]. [Бабкин О. В. Специальные виды туризма. Ростов-на-Дону: Феникс, 2008. 252 с.]

Beydik, O. (2001). Recreational and Tourist Resources of Ukraine: Methodology and Techniques of Analysis, Terminology, Zoning. Kyiv. [In Ukrainian]. [Бейдик О. О. Рекреаційно-туристичні ресурси України: Методологія та методика аналізу, термінологія, районування: Монографія. К.: Видавничо-поліграфічний центр «Київський університет», 2001, 395 с.]

Beidyk, O., Novosad, N., \& Topalova, O. (2016). Factors of development and features of event tourism. Chasopys kartohrafiji, 16, 125-131. [In Ukrainian]. [Бейдик О. О., Новосад Н. О., Топалова О. І. Чинники розвитку та особливості подієвого туризму // Часопис картографії. 2016. Вип. 16. С. 125-131.]

Belik, A. (1999). Culturology. Anthropological Theories of Cultures. Moscow. [In Russian]. [Белик А. А. Культурология. Антропологические теории культур. Учебноепособие. М.: РГГУ, 1999. С. 67-71.]

Birzhakov, М. (2000). Introduction to Tourism. Saint-Petersburg. [In Russian]. [Биржаков М. Б. Введение в туризм. СПб. Изд. Дом «Герда», 2000. 192 с.]

Boyko, O. (2011a). Leisure Culture: Transformations and Development Prospects in the Age of Globalization. Abstract of Doctoral Thesis. Kharkiv. [In Ukrainian]. [Бойко О. П. Культура дозвілля: трансформації та перспективи розвитку в добу глобалізації. Автореф. дис... д-ра філософ. наук 09.00.04. Харків. нац. пед. ін-т ім. Г. Сковороди. Х. 2011. 31 с.]

Boyko, О. (2011b). Culture of Leisure in Society of Risk. Sumy. [In Ukrainian]. [Бойко О. П. Культура дозвілля у суспільстві ризику: монографія. Суми: ДВНЗ «УАБСНБУ», 2011. 285 с.]

Bozhko, L. (2017). Tourism as a Socio-Cultural Phenomenon: History and Modernity (middle of XIX - beginning of XXI centuries). Kharkiv. [In Ukrainian]. [Божко Л. Д. Туризм как социокультурный феномен: история и современность (средина XIX - нач. XXI в.): монография. Харьков: Лидер, 2017. 344 с.]

Davydenko, I. (2012). Dominants of the event tourism market. In Development of Science in the Modern World: Proceedings of the International Scientific and Practical Conference (pp. 97-103). Krakow. [In Russian]. [Давыденко И. В. Доминанты рынка событийного туризма. Перспективы развития науки в современном мире : мат. междун. начно-практич. конф. Краков, 2012. С. 97-103.]

Doroga.ua. (2020). Sightseeings of Bilhorod-Dnistrovskyi: photos, addresses of museums, palaces, monasteries, churches, parks, reserves, etc. Rethrieved from: http://www.doroga.ua/pois/odeskaya/Belgorod-Dnestrovsky [In Ukrainian]. [Пам'ятки Білгорода-Дністровського: фото, адреси музеї, палаци, монастирі, церкви, парки, заповідники та ін. пам'ятки [Інтернет ресурс]. Режим доступу: http://www.doroga.ua/pois/odeskaya/BelgorodDnestrovskij]

Frolova, T. (2010). Economics and Management in the Field of Socio-Cultural Services and Tourism: Lecture Notes [Electronic resource]. Taganrog. Rethrieved from: http://www.aup.ru/books/m19/2_1.htm131. [In Russian]. [Фролова Т. А. Экономика и управление в сфере социально-культурного сервиса и туризма: конспект лекций. Таганрог: ТТИ ЮФУ, 2010. Режим доступа: http://www.aup.ru/books/m19/2_1.htm131.]

Interesting Places of Ukraine. (2020a). History of Odessa region. Rethrieved from: http://ua.interestingukraine. Kiev.ua/Odeska-oblast/istoriyaOdeskojioblasti/ [In Ukrainian]. [Цікаві місця України. Історія Одеської області [Інтернет ресурс]. Режим доступу: http//ua.interestingukraine. Kiev.ua/Odeska-oblast/istoriyaOdeskojioblasti/]

Interesting Places of Ukraine. (2020b). Interesting places and sights of Bilhorod-Dnistrovskyi. Rethrieved from: http://ua.interestingukraine. Kiev.ua/Odeska-oblast/istoriyaOdeskojioblasti//In Ukrainian]. [Цікаві місця України - Цікаві місця та пам'ятки м. Білгород-Дністровський [Інтернет ресурс]. Режим доступу: httр:/ ua.interestingukraine.Kiev.ua/Odeska-oblast/istoriyaOdeskojioblasti/]

Lakomov, E. (2013). Improving the Competitiveness of the Regions of Russia on the Basis of the Development of Event Tourism Services. Extract of PhD Thesis. Moscow. [In Russian]. [Лакомов Е. Ф. Повышение конкурентоспособности регионов России на основе развития услуг по событийному туризму: автореф. дисс. на соиск. уч. степени канд. экон. наук. М., 2013. 28 с.]

Nikitina, S., Zinchenko, M. (2012). Event as a basis for designing a tourist product. In Actual Problems of the Humanities: Proceedings of the International Scientific and Practical Conference (Tomsk, April 5-6, 2012) (pp. 8184). [In Russian]. [Никитина С. С., Зинченко М. В. Событие как основа для проектирования туристического продукта / Актуальные проблемы гуманитарных наук: Мат. Международной научно-практ. конф. (Томск, 5-6 апр. 2012 г.). Томск, 2012. С. 81-84]

Oliynyk, V., Shikina, O. (2016). The current state and prospects of development of event tourism in Ukraine. Global and National Issues of Economy, 14, 460-463. [In Ukrainian]. [Олійник В. В., Шикіна О. В. Сучасний стан та перспективи розвитку подієвого туризму на території України // Глобальні та національні проблеми економіки. 2016. Вип. 14. С. 460-463.]

Pazenok, V., Fedorchenko, V. (2004). Philosophy of Tourism. Kуiv. [In Ukrainian]. [Пазенок В. С., Федорченко 
В. К. Філософія туризму. К.: Кондор, 2004. 268 с.]

Smal, I. (2010). Tourist Resources of the World. Nizhyn: Gogol State University Publishing House. [In Ukrainian].

[Смаль I. В. Туристичні ресурси світу: навч. посібник. Ніжин: Вид-во НДУ ім. М. Гоголя, 2010. 336 с.]

Tereshkovich, P. (1998). Cultural anthropology. In A. Gritsanov (Ed.), The Actual Philosophical Dictionary: Encyclopedia (p. 896). Minsk. [In Russian]. [Терешкович П. В. Антропология культурная / Новейший философский словарь: Энциклопедия / Сост. А. А. Грицанов. Минск, 1998. С. 896.]

Tishchenko, P. (2011). Theoretical aspects and development of event tourism in the region. Scientific bulletin of the Uzhhorod University: Economics series, 33 (4), 124-128. [In Ukrainian]. [Тищенко П. В. Теоретичні аспекти та розвиток подієвого туризму регіону // Науковий вісник Ужгородського університету. Серія Економіка. 2011. Спецвипуск 33. Частина 4. С. 124-128.]

Sheiko, V. (2012). Globalization challenges and Ukraine: cultural and economic dimensions. In Objectification of Cultural Creation in the Age of Civilizational Globalization. Collection of Scientific works, National Academy of Arts of Ukraine, Vol. 2. (pp. 18-28). Kyiv. [In Ukrainian]. [Шейко В. М. Глобалізаційні виклики та Україна: культурологічно-економічні виміри // Об'єктивізація культуротворення в добу цивілізаційної глобалізації. Збірник наукових праць. Національна академія мистецтв України. Т.2. Київ. Інститут культурології, 2012. C. 18-28).]

Sheiko, V. (2017). Bibliographic index (to the 75th anniversary of birth). Kharkiv: KhDAK. [In Ukrainian]. [Шейко В. М. (до 75 річчя від дня народження). Бібліографічний показчик. Харків, ХДАК, 2017. 239 с.]

Shikina, O., Liptuga, I. (2017). Analysis of the structure of tourist flows of Odessa region. Global and national problems of economy, 7, 114-127. [In Ukrainian]. [Шикіна О. В., Ліптуга I. Л. Аналіз структури туристичних потоків Одеської області // Глобальні та національні проблеми економіки. 2015. № 7. С. 114-127.]

Shikina, O., Oliynyk, V. (2016). Current state and prospects of event tourism in Ukraine. Global and national economic problems, 12, 460-463. [In Ukrainian]. [Шикіна О. В., Олійник В. В. Сучасний стан та перспективи розвитку подієвого туризму на території України // Глобальні та національні проблеми економіки. Миколаївський нац. університет імені В. О. Сухомлинського. 2016. Вип. 12. С. 460-463.] 